AFRICAN AMERICAN ARTS 


\section{THE GRIOT PROJECT}

Series Editor: Carmen Gillespie, Bucknell University

This book series, associated with the Griot Project at Bucknell University, publishes monographs, collections of essays, poetry, and prose exploring the aesthetics, art, history, and culture of African America and the African diaspora.

The Griot is a central figure in many West African cultures. Historically, the Griot had many functions, including as a community historian, cultural critic, indigenous artist, and collective spokesperson. Borrowing from this rich tradition, the Griot Project Book Series defines the Griot as a metaphor for the academic and creative interdisciplinary exploration of the arts, literatures, and cultures of African America, Africa, and the African diaspora.

Expansive and inclusive in its appeal and significance, works in the Griot Project Book Series will appeal to academics, artists, and lay readers and thinkers alike.

\section{Titles in the Series}

Sharrell D. Luckett, ed., African American Arts: Activism, Aesthetics, and Futurity

Frieda Ekotto, Don't Whisper Too Much and Portrait of a Young Artiste from Bona Mbella

Vincent Stephens and Anthony Stewart, eds., Postracial America? An Interdisciplinary Study

James Braxton Peterson, ed., In Media Res: Race, Identity, and Pop Culture in the Twenty-First Century

Angèle Kingué, Venus of Khala-Kanti

Carmen Gillespie, ed., Toni Morrison: Forty Years in the Clearing

Myron Hardy, Catastrophic Bliss 


\section{AFRICAN AMERICAN ARTS}

Activism, Aesthetics, and Futurity

EDITED BY

SHARRELL D. LUCKETT

Bucknell | UNIVERSITY 
Library of Congress Cataloging-in-Publication Data

Names: Luckett, Sharrell D., editor. | African-American Arts : Activism and Aesthetics (Conference) (2016: Bucknell University)

Title: African American arts : activism, aesthetics, and futurity / edited by Sharrell D. Luckett.

Description: Lewisburg, Pennsylvania : Bucknell University Press, 2019.|

Series: The Griot project | Essays and presentations primarily prepared for The Griot Institute for Africana Studies' convening on African-American art, activism, and aesthetics held in fall 2016 at Bucknell University in Lewisburg, PA. | Includes bibliographical references and index.

Identifiers: LCCN 2019005251 | ISBN 9781684481521 (pbk. : alk. paper) | ISBN 9781684481538 (cloth : alk. paper)

Subjects: LCSH: African American arts-Political aspects. | Arts and society-United States. | United States-Civilization-21st century-Forecasting.

Classification: LCC NX512.3.A35 A35 2019 | DDC 700.89/96073-dc23

LC record available at https://lccn.loc.gov/2019005251

A British Cataloging-in-Publication record for this book is available from the British Library.

This collection copyright (C) 2020 by Bucknell University Press

Individual chapters copyright (C) 2020 in the names of their authors

All rights reserved

No part of this book may be reproduced or utilized in any form or by any means, electronic or mechanical, or by any information storage and retrieval system, without written permission from the publisher. Please contact Bucknell University Press, Hildreth-Mirza Hall, Bucknell University, Lewisburg, PA $17837-2005$. The only exception to this prohibition is "fair use" as defined by U.S. copyright law.

(The paper used in this publication meets the requirements of the American National Standard for Information Sciences_-Permanence of Paper for Printed Library Materials, ANSI Z39.48-1992.

www.bucknell.edu/UniversityPress

Distributed worldwide by Rutgers University Press

Manufactured in the United States of America 
This book is dedicated to Carmen Gillespie and Ntozake Shange. Rest in power and peace. 
